\title{
The Diet of Students of the Nizhny Tagil State Socio-Pedagogical Institute
}

\author{
Kozhevnikova Olga Anatolyevna ${ }^{1}{ }^{*}$ and Parkhomenko Dmitry Vyacheslavovich ${ }^{2}$ \\ ${ }^{1}$ Doctor of Medical Sciences, Russia \\ ${ }^{2}$ Student, Russian State Vocational Pedagogical University, Russia
}

*Corresponding author: Kozhevnikova Olga Anatolyevna, Doctor of Medical Sciences, Russia

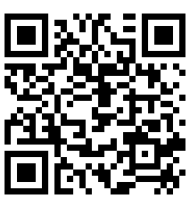

\section{ARTICLE INFO}

Received: 慧 February 10, 2020

Published: 㗀 February 19, 2020

Citation: Kozhevnikova Olga Anatolyevna, Parkhomenko Dmitry Vyacheslavovich. The Diet of Students of the Nizhny Tagil State Socio-Pedagogical Institute. Biomed J Sci \& Tech Res 25(5)-2020. BJSTR. MS.ID.004253.

ABSTRACT

In order to analyze the compliance of student's dietary regimen with hygienic requirements, a study was conducted among students of the 2nd year of the Faculty of Sports and Life Safety of the Nizhny Tagil State Social and Pedagogical Institute. We have developed special tables - "registration cards", where students independently entered data on their diet at time intervals corresponding to different levels of activity of the sympathetic department of the autonomic nervous system, for which the chronotype of each participant in the experiment was previously determined. We determined that only $8.3 \%$ of students observe a diet on protein distribution during the day and $33 \%$ of students follow a diet on fat distribution, that is, the majority of students have irrational nutrition, albeit regular with a sufficient duration of one meal. The quantitative and qualitative distribution of the daily diet for individual meals does not meet hygiene standards.
\end{abstract}

Keywords: Diet; Hygienic Assessment of Diet; Student Nutrition; Healthy Nutrition; Healthy Lifestyle; Nutritional Features of Modern Students; Rational Nutrition

\section{Introduction}

Under the diet, understand the meal at a set time and the most rational distribution of the daily diet during the day [1].

\section{The Diet Includes}

a) Regularity of nutrition - eating strictly at the same time of the day with the aim of developing a conditioned-reflex reaction of the secretory function of the gastrointestinal tract at the time of eating and ensuring the functional readiness of the body for its more efficient digestion and assimilation. The time of individual meals in an organized group is determined by the institution's working hours for children and adolescents [2].

b) The frequency and intervals between meals - the number of meals changes as a child grows older. Optimal for children and adolescents is eating with an interval of 3.5-4 hours in order to timely unload the gastrointestinal tract and equal to the needs of the body without undue stress on the main functional systems of providing it with energy and nutrients. c) Sufficient duration of one meal - on average, the duration of one meal of breakfast or dinner should be 10-15 minutes, lunch 25-30 minutes, excluding "hasty food" in order to ensure the proper degree of grinding, processing food in the oral cavity and facilitate the process of digestion subsequent sections of the gastrointestinal tract [4].

d) Quantitative and qualitative distribution of the daily diet in separate doses for the purpose of uniform delivery of nutrients to the body and timely replenishment of the metabolism during the day [3].

To achieve the goal of our study on dietary compliance, we used a survey method of research.

To achieve the goal of our study on dietary compliance, we used a survey method of research.

All research material was obtained on the basis of the Nizhny Tagil State Socio-Pedagogical Institute (branch) of the Federal State 
Autonomous Educational Institution of Higher Education "Russian State Vocational Pedagogical University" of the Department of Life Safety and Physical Culture. The study involved study groups 201OBFK in the amount of 12 students.

\section{At the Time of the Study, Students Were Aged 19-20 Years}

At this age, the whole organism of students develops. There is an increase in body size, an increase in the size of the lung volume. At this age, more than ever, a diet is needed. Both the state of health and the state of health of the body directly depend on the proper organization of the diet of students. The team is quite efficient, all students have the skills of independent mental work, the need for creative and physical activity is felt. In general, the class is very friendly, there were no conflicts between the students, the guys are responsive to each other, ready to help any of their classmates. We performed an analysis of the diet by comparing the results obtained and the normative data of the daily intake of macronutrients. The worksheet consisted of 4 columns. At the first stage of work, students entered the data of their diet with an indication of the interval of time for eating. In the second column, students entered the amount of protein intake at time intervals corresponding to different levels of activity of the sympathetic part of the autonomic nervous system, for which the chronotype of each participant in the experiment was previously determined. In the third - how much fat is consumed. In the fourth column, dietary compliance indicators were entered (Table 1).

Table 1: The distribution of proteins during the day according to active.

\begin{tabular}{|c|c|c|c|c|}
\hline $\begin{array}{c}\text { Time Intervals/ } \\
\text { Experiment Participants }\end{array}$ & $\mathbf{0 5 : 0 0 - 1 1 : 0 0}$ & $\mathbf{1 1 : 0 0 - 1 6 : 0 0}$ & $\mathbf{1 6 : 0 0 - 2 4 : 0 0 / 2 2 : 0 0}$ & $\mathbf{2 4 : 0 0 / 2 2 : 0 0 - 0 5 : 0 0}$ \\
\hline 1 & 5,9 & 25 & 16,4 & 0 \\
\hline 2 & 7,9 & 21,4 & 21,1 & 0 \\
\hline 3 & 27 & 3,9 & 40,2 & 0 \\
\hline 4 & 3,8 & 47,2 & 41,8 & 0 \\
\hline 5 & 8,2 & 6,3 & 38,1 & 0 \\
\hline 6 & 6,7 & 35,8 & 31,9 & 0 \\
\hline 7 & 9,2 & 2,54 & 21,4 & 0 \\
\hline 8 & 5,97 & 12,7 & 42,4 & 0 \\
\hline 9 & 6,2 & 3,4 & 21,2 & 0 \\
\hline 11 & 11,4 & 33,1 & 69,3 & 0 \\
\hline 12 & 34,4 & 52,5 & 38,1 & 0 \\
\hline
\end{tabular}

When analyzing the distribution of proteins during the day, according to the activity of the autonomic nervous system, we see that the first student ate 5.9 grams of protein with breakfast, 25 grams of protein for lunch, and 16.4 grams of protein for dinner; the second student consumed 7.9 grams of protein with food for breakfast, 21.4 grams of protein for lunch, and 21.1 grams of protein for dinner; the third student used 27 grams of protein with breakfast for food, 3.9 grams of protein for lunch, and 40.2 grams of protein for dinner, the fourth student consumed 3.8 grams of protein for breakfast, 47.2 grams of protein for lunch, and for dinner, 41.8 grams of protein; the fifth student consumed 8.2 grams of protein with food for breakfast, 6.3 grams of protein for lunch, and 38.1 grams of protein for dinner; the sixth student at breakfast consumed 6.7 grams of protein with food, 35.8 grams of protein for lunch, and 31.9 grams of protein for dinner; the seventh student at breakfast consumed 9.2 grams of protein with food, 2.54 grams of protein at lunch, and 21.4 grams of protein at dinner; the eighth student at breakfast consumed 5.97 grams of protein with food, at lunchtime 12.7 grams of protein, and at dinner 42.4 grams of protein; the ninth student at breakfast consumed 6.2 grams of protein with food, 3.4 grams of protein for lunch, and 7.84 grams of protein for dinner; the tenth student consumed 11.4 grams of protein with food for breakfast, 33.1 grams of protein for lunch, and 21.2 grams of protein for dinner; the eleventh student at breakfast consumed 34.4 grams of protein with food, 52.5 grams of protein at lunch, and 69.3 grams of protein at dinner; the twelfth student consumed 28.3 grams of protein with food for breakfast, 14.3 grams of protein for lunch, and 38.1 grams of protein for dinner.

Based on these data, it can be found that only one student observes a uniform distribution of proteins per day. And also, that half or more proteins were consumed at lunchtime in six students. When analyzing fat intake at lunchtime, we see that the first student ate lunch 1.32 grams of fat; the second student consumed 6.42 grams of fat at lunch; the third student consumed 32.9 grams of fat in lunch; the fourth student consumed 54.8 grams of fat in lunch; the fifth student consumed 32.47 grams of fat for lunch; the sixth student ate 1.75 grams of fat for lunch; the seventh student consumed 28.9 grams of fat for lunch; the eighth student consumed 48.6 grams of fat for lunch; the ninth student ate 8 grams of fat for lunch; the tenth student ate 0.28 grams of fat for lunch; the eleventh student consumed 7.5 grams of fat for lunch; the twelfth student consumed 2.4 grams of fat for lunch; Thus, half or more fat was consumed at lunch time in four people, which amounted to $33 \%$. 
When analyzing the distribution of proteins during the day, we see that of the twelve students, one has evenly distributed proteins during the day and the percentage was 8.3 . Thus, we determined that only $8.3 \%$ of students observe a diet on the distribution of proteins during the day and $33 \%$ of students observe a diet on the distribution of fats, that is, the nutrition of the bulk of students is erratic, although regular with a sufficient duration of one intake food. The quantitative and qualitative distribution of the daily diet for individual meals does not meet hygiene standards.

\section{References}

1. Dedkova LS (2015) Hygienic assessment of nutrition. In the collection: Medicine and healthcare. Materials of the III international scientific conference p. 75-81.

\section{ISSN: 2574-1241}

DOI: 10.26717/BJSTR.2020.25.004253

Kozhevnikova Olga Anatolyevna. Biomed J Sci \& Tech Res

(C) This work is licensed under Creative Submission Link: https://biomedres.us/submit-manuscript.php
2. Ilyicheva IM, Belous EN (2018) Features of nutrition of modern students. Hygiene and sanitation 97(4): 362-366.

3. Kuchma VR (2016) Guidance on hygiene and health protection. VR Kuchma, GR Serdyukovskaya, AK Demin M Russian Association of Public Health p. 152.

4. Makarova LG (2018) Fundamentals of the rational nutrition of a healthy student. LG Makarova, O Yu Kutumova: method, guidelines, nutrition technology p. 32.

$\begin{array}{ll}\text { BIOMEDICAL } & \text { Assets of Publishing with us } \\ \text { RESEARCHES } & \text { - Global archiving of articles } \\ & \text { - Immediate, unrestricted online access } \\ & \text { - Rigorous Peer Review Process } \\ & \text { - Anttps://biomedres.us/ }\end{array}$

